\title{
A facultative association between Plebeia droryana (Friese, 1900) (Hymenoptera: Apidae: Meliponini) and a wax scale insect, Ceroplastes janeirensis (Hemiptera: Coccoidea: Coccidae)
}

\author{
Peronti, ALBG.*, Fernandes, LBR. and Fernandes, MA. \\ Departamento de Ecologia e Biologia Evolutiva, Universidade Federal de São Carlos - UFSCar, \\ CP 676, CEP 13565-905, São Carlos, SP, Brazil \\ *e-mail: anaperonti@hotmail.com.br
}

Received May 2, 2012 - Accepted July 19, 2012 - Distributed May 31, 2013

(With 2 figures)

Ants and bees (Hymenoptera) are frequently associated with scale insects (Hemiptera: Coccoidea) and other Sternorrhyncha in a mutualistic relationship. Associations with ants are best known, and they tend to clean, protect and even transport these insects in exchange for honeydew (Way, 1963).

Studies between coccoids and bees are less common, although in some regions of Europe the associations between Apis sp. (Hymenoptera: Apidae) and scale insects are important for honey production (Santas, 1983; Gounari, 2006). In Brazil, the interaction between Apis mellifera and Stigmacoccus spp. (Coccoidea: Stigmacoccidae) associated to Mimosa scabrella (Fabaceae) was studied in relation to the production of molasses in Campos de Cima da Serra, Rio Grande do Sul (Witter et al., 2010).

Camargo and Pedro (2002a, b) reported a new kind of mutualistic association between the Amazonian stingless bee Schwarzula coccidophila Camargo and Pedro, 2002 (Hymenoptera: Apidae: Meliponini) and Cryptostigma sp. (Hemiptera: Coccoidea: Coccidae) in which the stingless bees not only collect the honeydew, but also the waxy cover produced by the scale insect which they use as an alternative source for construction of their nests. Schwarzula coccidophila maintain the scale insect Cryptostigma sp. inside their nests providing a safe place for them, far from the reach of natural enemies (Camargo and Pedro, 2002a, b). Camargo and Pedro (2002b) also provided a review of the stingless bees Schwarzula timida (Silvestri, 1902) at Coxipó, MT, Brazil and Plebeia emerina (Friese, 1900) (at São Paulo, SP, Brazil) associated with unidentified soft scale insect (Coccidae).

The coccid Cryptostigma sp. mentioned in association with $S$. coccidophila by Camargo and Pedro (2002a, b) was later described as a new species by Kondo (2010) who described it as Cryptostigma melissophilum Kondo. Kondo (2010) also described a second species, C. chacoensis Kondo, associated with stingless bees, which is found inside the nests of two stingless bees, S. timida and Plebeia sp. (D. Roubik, personal communication apud Kondo, 2010).

In the present report, Plebeia droryana (Friese, 1900) was collected in association with Ceroplastes janeirensis Gray, 1828 (Hemiptera: Coccoidea: Coccidae) (Figure 1), in December 2007, on Myrcia cauliflora Berg. (Myrtaceae) in an urban area of Araraquara, São Paulo, Brazil, located between the coordinates $21^{\circ} 58^{\prime}-22^{\circ} 00^{\prime} \mathrm{S}$ and $47^{\circ} 51^{\prime}-47^{\circ} 52^{\prime} \mathrm{W}$.
Additional samples were collected between January and August 2009, in order to confirm this novel scale insect interaction. The scale insects and bees were stored separately in 75 and $100 \%$ ethanol respectively.

The coccoid was mounted on microscopic slides following the methodology described by Gullan (1984), and identified according to Peronti et al. (2008). The bee specimens were sent to a specialist for identification. All specimens are deposited at the Universidade Federal de São Carlos, SP, Brazil.

The specimens of Ceroplastes janeirensis collected had their wax test completely or almost completely removed by the bees (Figure 2). The absence of the wax test, which is responsible for protection of these coccids, causes dehydration of the coccids and facilitates the action of

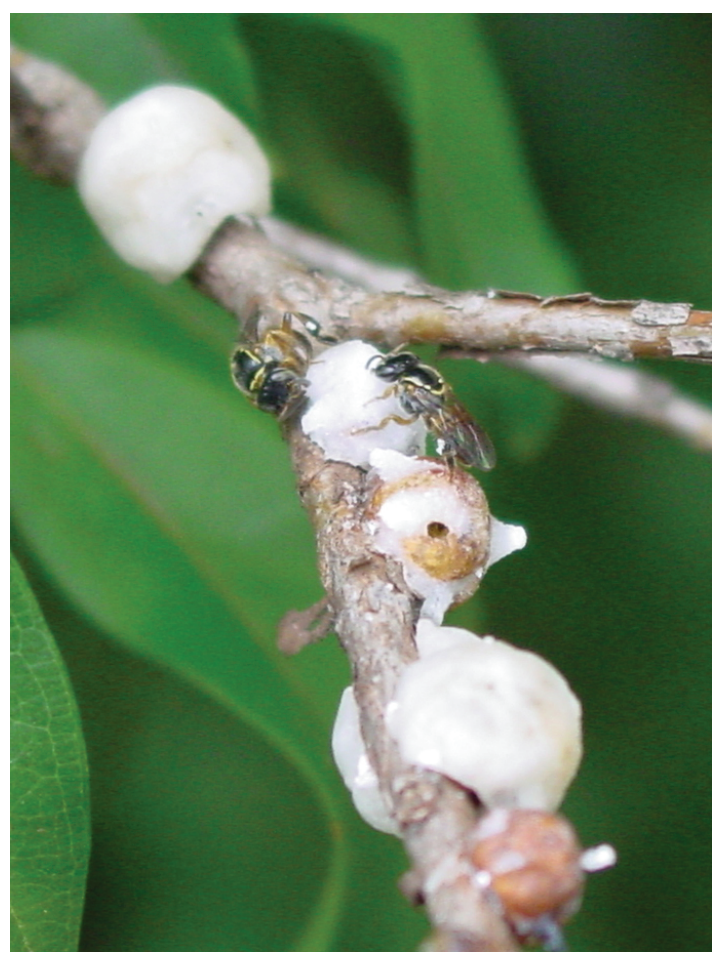

Figure 1. Plebeia droryana removing the waxy test of Ceroplastes janeirensis. 


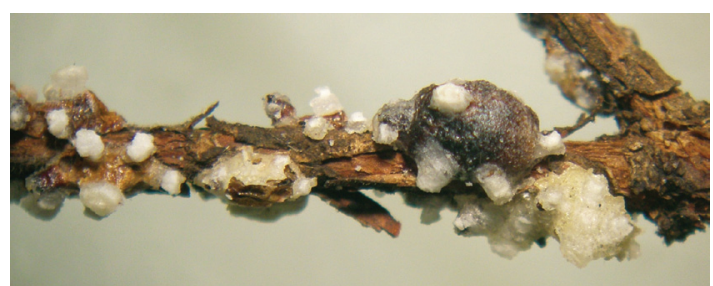

Figure 2. Ceroplastes janeirensis with waxy test removed by the bees.

natural enemies, leaving them more vulnerable. In this case, the interaction appears to be negative for the scale insects.

The use of the coccid wax obtained by $P$. droryana remains unknown, but according to the literature, we suggest that it is probably used for the construction of their nests.

Acknowledgements - To Prof. Dr. José Maria Franco de. Camargo (in memorium) for the identification of Plebeia droryana (Friese, 1900); and to Dr. Takumasa Kondo (CORPOICA, Palmira, Colombia) for reviewing the manuscript.

\section{References}

CAMARGO, JMF. and PEDRO, SRM., 2002a. Mutualistic association between a tiny Amazonian stingless bee and a wax producing scale insect. Biotropica, vol. 34, no. 3, p. 446-451.

-, 2002b. Uma especie nova de Schwarzula da Amazonia (Hymenoptera, Apidae, Meliponini). Iheringia, Série Zoologia, vol. 92, no. 3, p. 101-112.
GOUNARI, S., 2006. Studies on the phenology of Marchalina hellenica (gen.) (Hemiptera: Coccoidea, Margarodidae) in relation to honeydew flow. Journal of apicultural research, vol. 45, no. 1, p. 8-12. http://dx.doi.org/10.3896/IBRA.1.45.1.03

GULLAN, PJ., 1984. A revision of the gall-forming coccoid genus Apiomorpha Rübsaamen (Homoptera: Eriococcidae: Apiomorphinae). Australian Journal of Zoology, Supplementary Series, vol. 97, p. 1-203.

KONDO T., 2010. Taxonomic revision of the myrmecophilous, meliponiphilous and rhizophilous soft scale genus Cryptostigma Ferris (Hemiptera: Coccoidea: Coccidae). Zootaxa, vol. 2709, p. 1-72.

PERONTI, ALBG., SOUSA-SILVA, CR. and GRANARA DE WILLINK MC., 2008. Revision of the species of Ceroplastinae Atkinson (Hemiptera, Coccoidea, Coccidae) from the state of São Paulo, Brazil. Revista Brasileira de Entomologia, vol. 52, no. 2, p. 139-181. http://dx.doi.org/10.1590/S0085-56262008000200001

SANTAS, LA., 1983. Insects producing honeydew exploited by bees in Greece. Apidologie, vol.14, no. 2, p. 93-103. http://dx.doi. org/10.1051/apido:19830204

WAY, MJ., 1963. Mutualism between ants and honeydew-producing Homoptera. Annual Review Entomology, vol. 8, p. 307-344.

WITTER, S., WOLFF, VRS., LISBOA, BB., LOPES, LA., BLOCHTEIN, B. and IMPERATRIZ-FONSECA, VL., 2010. Abelhas (Apidea) e cochonilhas (Stigmacoccidae) associadas à bracatinga para a produção de melato nos Campos de Cima da Serra, RS, Brasil. In: Anais do IX Encontro sobre Abelhas, 2010. Ribeirão Preto. v. 3.3, p. 579-579. 